\title{
The ecology of Aedes aegypti and Aedes albopictus larvae habitat in coastal areas of South Sulawesi, Indonesia
}

\author{
ARINI RATNASARI ${ }^{1, \bullet}$, ARIF RAHMAN JABAL ${ }^{2}$, NUR RAHMA ${ }^{3}$, SRI NUR RAHMI ${ }^{3}$, MILA KARMILA ${ }^{3}$, \\ ISRA WAHID ${ }^{3, \% \varphi}$ \\ ${ }^{1}$ Graduate School, Faculty of Medicine, Universitas Hasanuddin. Jl. Perintis Kemerdekaan Km. 10, Makassar 902425, South Sulawesi, Indonesia \\ Tel./fax.: +62-411-586200, `email: ratnasaria18c@student.unhas.ac.id \\ ${ }^{2}$ Departmen of Parasitology, Faculty of Medicine, Universitas Palangka Raya. Palangka, J1. Jekan Raya, Palangka Raya 74874, Central Kalimantan, Indonesia \\ ${ }^{3}$ Faculty of Medicine, Universitas Hasanuddin. Jl. Perintis Kemerdekaan Km. 10, Makassar 902425, South Sulawesi, Indonesia. Tel.: +62-411-586200, \\ Fax.: +62-411-584200, , email: israwahid@med.unhas.ac.id
}

Manuscript received: 25 July 2020. Revision accepted: 17 September 2020.

\begin{abstract}
Ratnasari A, Jabal AR, Rahma N, Rahmi SN, Karmila M, Wahid I, 2020. The ecology of Aedes aegypti and Aedes albopictus larvae habitat in coastal areas of South Sulawesi, Indonesia. Biodiversitas 21: 4648-4654. Aedes aegypti and Aedes albopictus are arbovirus vectors that can adapt to various environmental conditions. This study aimed to analyze the spatial distribution, habitat characteristics, and the correlation between the number of Ae. aegypti and Ae. albopictus larvae with physical factors. The larvae were collected from seven sampling locations along the coast of South Sulawesi at a distance of $100 \mathrm{~m}, 500 \mathrm{~m}, 1 \mathrm{~km}$, and $2 \mathrm{~km}$ from the coastline. The collected samples and their water habitat were examined in the Entomology Laboratory of the Faculty of Medicine, Hasanuddin University, South Sulawesi, Indonesia. The number of larvae was counted (3182 larvae of both kinds), and the pH and salinity of the water were measured. Data analysis was performed with IBM SPSS version 24 and spatial distribution of larvae was mapped with ArcGIS version 10.5. We found that the highest number of Ae. aegypti was at a distance of $100 \mathrm{~m}$ from the coastline (73.34\%), while Ae. albopictus was at $500 \mathrm{~m}(34.14 \%)$. Most of the mosquitos laid their eggs on discarded boats as observed in the Kurri Caddi coast (31.2\%). The observed ranges of $\mathrm{pH}$, salinity, and temperature of larvae habitat were 5.5-6.4, 5-2 ppt, and $28-31^{\circ} \mathrm{C}$, respectively. The total number of larvae had a significant correlation $\mathrm{p}<0.05$ with the physical factors, i.e., distance from the coastline, water $\mathrm{pH}$, temperature, and kind of water storages (containers). This study showed that physical factors in the coastal area significantly influenced the habitat characteristics and the abundance of Ae. aegypti and Ae. albopictus larvae.
\end{abstract}

Keywords: Ae. aegypti, Ae. albopictus, coastal area, South Sulawesi

\section{INTRODUCTION}

Mosquito distribution should be monitored since it could be a vector and potentially spread disease (Pratiwi et al. 2019). Aedes sp. can transmit illnesses such as zika, yellow fever, chikungunya, and dengue (Kauffman et al. 2017). Symptoms of dengue infection vary, consisting of classic dengue fever (DF), dengue hemorrhagic fever (DHF), and dengue shock syndrome (Sasmono et al. 2015). In 2017, 68407 people suffered from DHF in Indonesia, while 1737 cases of dengue occurred in South Sulawesi, Indonesia and it increased to 2122 cases in the following year (Ministry of Health 2018).

Aedes aegypti and Aedes albopictus are members of the family Culicidae, and these mosquitoes are invasive species that are expeditiously and widely spread (Paupy et al. 2010). Female mosquitoes need a host as a source of food for laying eggs and life processes. To date, around 3500 species of Culicidae are found in tropical climate regions (Wilkerson et al. 2015). According to Lubinda et al. (2019), Ae. aegypti and Ae.albopictus are well adjusted to a temperature range between -6 and $21.5^{\circ} \mathrm{C}$. Ae. aegypti larvae are mostly found in a shady place with water (Soares-da-Silva et al. 2012). In addition, the larvae can also be found in wells, drains, roof gutters, elevated water tanks, and even septic tanks (Arana-Guardia et al. 2014).

Ae. albopictus tends to oviposite in parts of plants that can store water (Silva et al. 2018), and it is adapted to various environmental conditions in the tropics and subtropics (Ibáñez-Justicia et al. 2020). Ae. aegypti is more dominant as a vector for dengue transmission than $A e$. albopictus (Lambrechts et al. 2010). The latest report showed that Ae. aegypti and Ae. albopictus oviposited and experienced pre-imaginal developments in brackish water in plastic containers, glasses, abandoned vessels, and wells in coastal areas (Ramasamy et al. 2011).

Over the coast of South Sulawesi, reports on the ecology of larval habitats of Ae. aegypti and Ae. albopictus is lacking. Dengue virus vector habitat is not only found in residential areas but also in coastal areas. Eradication of the vector on the coastal areas far from the settlement needs to be a serious concern. It is urgent to know where mosquitoes breed, and analysis of salinity is imperative to anticipate the spread of dengue. This study aimed to analyze the distribution of larvae, the habitat characteristics of Ae. aegypti and Ae. albopictus, and the correlation between physical factors and the number of individual larvae. This research expects to provide information related to the ecology of Ae. aegypti and Ae. albopictus larvae for integrated prevention and control of dengue vectors. 


\section{MATERIALS AND METHODS}

The observational study was employed with a simple random sampling design to determine the spatial distribution of Ae. aegypti and Ae. albopictus larvae and habitat characteristics in coastal regions in South Sulawesi, Indonesia.

\section{Study area}

The mosquito larvae were collected on the coast of South Sulawesi from July to December 2019. The dry season was from April to October, and the rainy season started from November to March 2019 in South Sulawesi. The average rainfall intensity is between $338 \mathrm{~mm}$ and 458 $\mathrm{mm}$ in 2019 (BMKG 2019). Seven sampling locations on seven Sub-districts were selected, considering the administrative location variation, outskirt location with easy access, and the high number of dengue cases (Table 1, Figure 1).

\section{Mosquito collection}

Sampling was carried out from the morning to noon (8:00 to 12:00 local time) by searching for Aedes aegypti and Aedes albopictus mosquito breeding habitat at some distance from coastline, i.e., 0-100m, $100-500 \mathrm{~m}, 0.5-1 \mathrm{~km}$, and $1-2 \mathrm{~km}$. All mosquito larvae were collected using a Pasteur pipette (10-cm diameter filter) for small (large) number of samples. The water salinity of larvae habitat was measured with a salinometer (Atago, Japan). The instrument was calibrated with a solution of 0 to $30 \mathrm{ppt}$ sodium chloride in the laboratory, and the measurement of water $\mathrm{pH}$ and temperature was done using $\mathrm{pH}$ meter and thermometer respectively. All mosquito larvae with water in the containers were transferred to the sample bottles and labelled, then the distance of the sample coordinates from the coastline was measured using GPS (Garmin Montana 680). All samples were brought to the Entomology Laboratory of Hasanuddin University.

\section{Identification of mosquitoes}

The collected mosquito larvae were grouped and counted based on the sampling location. The larvae were placed on glass objects using a needle. The observation was conducted with a stereo microscope with 100x magnification using a taxonomic identification key of mosquito larvae, from Ministry of Health, Republic of Indonesia (2017).

\section{Data analysis}

Data were presented with chi-square analysis to find out the percentage of larvae on their specific habitat. Meanwhile, the correlation between the number of larvae collected in each region and the physical factors was analyzed with the Pearson correlation, the spatial distribution of larvae was analyzed with IBM SPSS version 24 , and the spatial distribution of larvae was mapped with ArcGIS version 10.5 application.
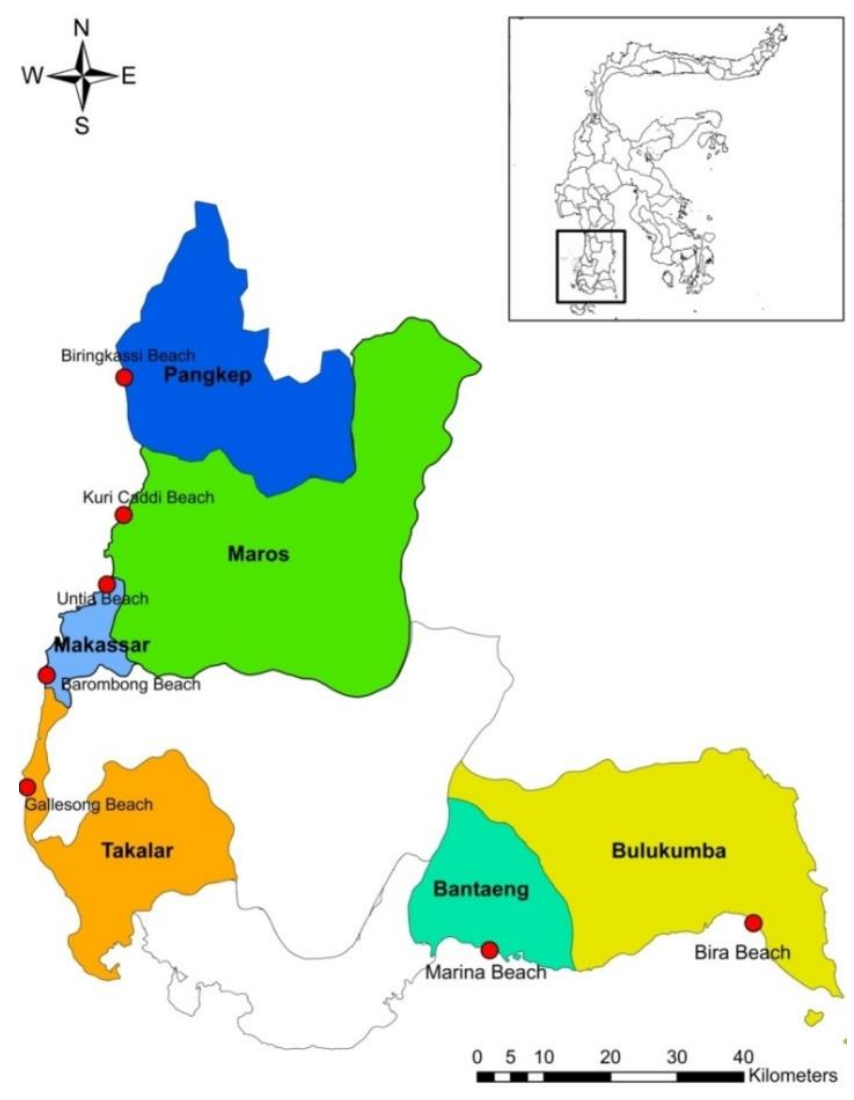

Figure 1. Map of South Sulawesi, Indonesia with seven beach locations based on the brackish water collection of Ae. aegypti and Ae. albopictus pra-imaginal stage (red marker)

Table 1. Location of study area at the coast of South Sulawesi, Indonesia

\begin{tabular}{|c|c|c|c|}
\hline Location & Sub-district & City/district & Latitude/longitude \\
\hline Untia beach & Biringkanaya & Makassar & $5^{\circ} 04^{\prime} 00.2^{\prime \prime} \mathrm{S}$ and $119^{\circ} 28^{\prime} 26.9^{\prime \prime} \mathrm{E}$ \\
\hline Barombong beach & Tamalate & Makassar & $5^{\circ} 12^{\prime} 25.1 " \mathrm{~S}$ and $119^{\circ} 23^{\prime} 00.3{ }^{\prime \prime} \mathrm{E}$ \\
\hline Kuri Caddi beach & Marussu & Maros & $5^{\circ} 01 ' 55.1 " \mathrm{~S}$ and $119^{\circ} 28^{\prime} 01.6 " \mathrm{E}$ \\
\hline Gallesong beach & Galesong & Takalar & $5^{\circ} 14^{\prime} 29.8^{\prime \prime} \mathrm{S}$ and $119^{\circ} 22^{\prime} 48.5^{\prime \prime} \mathrm{E}$ \\
\hline Marina beach & Pa'jukukang & Bantaeng & $5^{\circ} 35^{\prime} 05.3$ 'S and $120^{\circ} 06^{\prime} 02.3{ }^{\prime \prime} \mathrm{E}$ \\
\hline Bira beach & Bonto Bahari & Bulukumba & $5^{\circ} 36^{\prime} 53.9^{\prime \prime} \mathrm{S}$ and $120^{\circ} 27^{\prime} 23.5^{\prime \prime} \mathrm{E}$ \\
\hline Biringkassi beach & Bungoro & Pangkajene Kepulauan & $4^{\circ} 81^{\circ} 26.0^{\prime \prime} \mathrm{S}$ and $119^{\circ} 49^{\prime} 72.0^{\prime \prime} \mathrm{E}$ \\
\hline
\end{tabular}




\section{RESULTS AND DISCUSSION}

\section{The distribution of larvae}

A total of 3182 larvae were collected during the field observation, consisting of two species, Ae. aegypti $(\mathrm{n}=2266)$ and Ae. albopictus $(\mathrm{n}=916)$. The distribution of larvae of both species is presented in Table 2 and shown in Figure 2. The most abundant Ae. aegypti larvae were found at $100 \mathrm{~m}$ and Ae. albopictus $500 \mathrm{~m}$ from coastline (Table 2).

The abundance of Ae. aegypti and Ae. albopictus in coastal habitats according to the distance from each region varies. At a distance of 100 meters, 500 meters, 2 kilometers the number of Ae. aegypti larvae was the highest in the Biringkassi beach, and a distance of 1 kilometer in the Kuri Caddi beach. As for the Ae. albopictus larvae, at distance of 100 meters the highest number was found in Untia beach, at 500 meters in Gallesong beach, at 1 kilometer in Kuri Caddi beach, and at 2 kilometers in Barombong beach (Table 2).

\section{Habitat characteristics}

Ae. aegypti and Ae. albopictus have different preferences for habitat. While Ae. aegypti usually develops inside human-made containers and lives close to human settlements, Ae. albopictus generally grows in habitat far from households. The type of container which had the highest percentage of larvae differed from one place to another. In general, four types of container had high percentage of larvae, i.e., discarded boat, water drum, discarded bucket, and used tire (Table 3 and Figure 3).

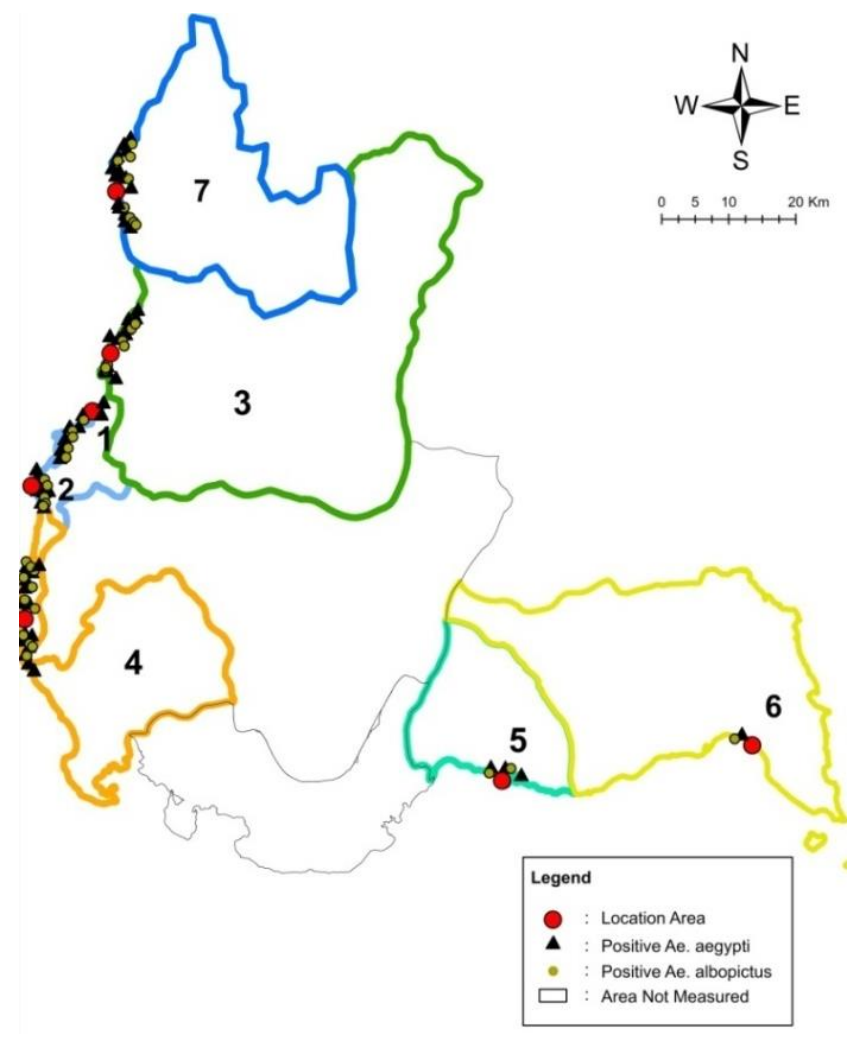

Figure 2. Map of distribution of Ae.aegypti and Ae.albopictus larvae in the coastal area of South Sulawesi, Indonesia

Tabel 2. Distribution of larvae of Ae. aegypti dan Ae. albopictus in the coastal habitat according to the distance from the coastline

\begin{tabular}{|c|c|c|c|c|c|c|}
\hline \multirow{2}{*}{ Species } & \multirow{2}{*}{ Location } & \multicolumn{4}{|c|}{ Distance from coastline } & \multirow{2}{*}{ Total } \\
\hline & & $100 \mathrm{~m}$ & $500 \mathrm{~m}$ & $1 \mathrm{~km}$ & $2 \mathrm{~km}$ & \\
\hline \multirow[t]{8}{*}{ Aedes aegypti } & 1 & $187(17.81 \%)$ & $95(13.40 \%)$ & 0 & 0 & 282 \\
\hline & 2 & $92(8.76 \%)$ & $4(0.56 \%)$ & $64(7.41 \%)$ & $134(23.97 \%)$ & 294 \\
\hline & 3 & $113(10.76 \%)$ & $31(4.37 \%)$ & $375(43.40 \%)$ & $118(21.11 \%)$ & 637 \\
\hline & 4 & $70(6.67 \%)$ & $115(16.22 \%)$ & $60(6.94)$ & 0 & 245 \\
\hline & 5 & $2(0.19 \%)$ & 0 & 0 & 0 & 2 \\
\hline & 6 & $2(0.19 \%)$ & 0 & 0 & 0 & 2 \\
\hline & 7 & $304(28.95 \%)$ & $222(31.31 \%)$ & $143(16.55 \%)$ & $135(24.15 \%)$ & 804 \\
\hline & & $770(73.34 \%)$ & $467(65.86 \%)$ & $642(74.30 \%)$ & $387(69.23 \%)$ & 2266 \\
\hline \multirow[t]{8}{*}{ Aedes albopictus } & 1 & $89(8.48 \%)$ & $59(8.32 \%)$ & 0 & 0 & 148 \\
\hline & 2 & $28(2.67 \%)$ & $1(0.14 \%)$ & $17(1.97 \%)$ & $79(14.13 \%)$ & 125 \\
\hline & 3 & $49(4.67 \%)$ & $3(0.42 \%)$ & $154(17.82 \%)$ & $36(6.44 \%)$ & 242 \\
\hline & 4 & $13(1.24 \%)$ & $146(20.59 \%)$ & $21(2.43 \%)$ & 0 & 180 \\
\hline & 5 & $16(1.52 \%)$ & 0 & 0 & 0 & 16 \\
\hline & 6 & $16(1.52 \%)$ & 0 & 0 & 0 & 16 \\
\hline & 7 & $69(6.57 \%)$ & $33(4.65 \%)$ & $30(3.47 \%)$ & $57(10.20 \%)$ & 189 \\
\hline & & $280(26.66 \%)$ & $242(34.14 \%)$ & $222(25.70 \%)$ & $172(30.77 \%)$ & 916 \\
\hline Total $(\%)$ & & $1050(100 \%)$ & $709(100 \%)$ & $864(100 \%)$ & $559(100 \%)$ & 3182 \\
\hline
\end{tabular}

Note: Location 1. Untia beach, 2. Barombong beach, 3. Kuri Caddi beach, 4. Gallesong beach, 5. Marina beach, 6. Bira beach, 7. Biringkassi beach 
Table 3. Container types and the percentage of Ae. aegypti and Ae. albopictus larvae found in each container type in the coastal area

\begin{tabular}{|c|c|c|c|c|c|c|c|c|c|c|}
\hline \multirow{2}{*}{ Container type } & \multirow{2}{*}{$\begin{array}{c}\text { Number of } \\
\text { inspected } \\
\text { larvae (n) }\end{array}$} & \multirow{2}{*}{ Ae. aegypti } & \multirow{2}{*}{ Ae. albopictus } & \multicolumn{7}{|c|}{ Percentage of larvae found $(\%)$} \\
\hline & & & & 1 & 2 & 3 & 4 & 5 & 6 & 7 \\
\hline Petal leaf & 5 & 3 & 1 & 3.2 & 1.4 & 1.1 & 0.0 & 0.0 & 0.0 & 0.0 \\
\hline Stone hole & 5 & 2 & 1 & 3.2 & 0.0 & 0.0 & 0.0 & 0.0 & 5.0 & 1.2 \\
\hline Tree hole & 5 & 1 & 0 & 1.1 & 1.4 & 2.2 & 0.0 & 0.0 & 0.0 & 1.2 \\
\hline Ground hole & 5 & 2 & 0 & 1.1 & 1.4 & 2.2 & 1.6 & 0.0 & 0.0 & 0.0 \\
\hline Discarded boat & 100 & 53 & 35 & 14.7 & 23.3 & 31.2 & 19.4 & 23.8 & 15.0 & 23.3 \\
\hline Water drums & 100 & 40 & 26 & 15.8 & 24.7 & 20.4 & 25.8 & 23.8 & 25.0 & 25.6 \\
\hline Discarded bucket & 50 & 20 & 11 & 12.6 & 9.6 & 7.5 & 11.3 & 14.3 & 15.0 & 12.8 \\
\hline Flower pot & 30 & 10 & 5 & 4.2 & 11.0 & 6.5 & 8.1 & 9.5 & 10.0 & 3.5 \\
\hline Discarded gallon & 5 & 1 & 3 & 3.2 & 0.0 & 1.1 & 1.6 & 0.0 & 0.0 & 0.0 \\
\hline Plastic cup & 10 & 6 & 2 & 6.3 & 0.0 & 2.2 & 1.6 & 4.8 & 0.0 & 0.0 \\
\hline Discarded tire & 100 & 43 & 39 & 29.5 & 20.5 & 17.2 & 19.4 & 9.5 & 15.0 & 27.9 \\
\hline Discarded foam & 5 & 2 & 1 & 0.0 & 0.0 & 2.2 & 3.2 & 0.0 & 0.0 & 1.2 \\
\hline Discarded can & 5 & 2 & 2 & 0.0 & 2.7 & 1.1 & 1.6 & 4.8 & 0.0 & 0.0 \\
\hline Discarded launchbox & 5 & 1 & 0 & 2.1 & 1.4 & 0.0 & 0.0 & 0.0 & 5.0 & 1.2 \\
\hline Discarded water dipper & 5 & 1 & 0 & 0.0 & 1.4 & 0.0 & 1.6 & 4.8 & 5.0 & 1.2 \\
\hline Discarded pan & 10 & 1 & 4 & 3.2 & 1.4 & 1.1 & 4.8 & 4.8 & 0.0 & 1.2 \\
\hline Discarded pool & 5 & 3 & 1 & 0.0 & 0.0 & 4.3 & 0.0 & 0.0 & 5.0 & 0.0 \\
\hline Total & 450 & 191 & 131 & 100 & 100 & 100 & 100 & 100 & 100 & 100 \\
\hline
\end{tabular}

Note: 1. Untia, 2. Barombong, 3. Kuri caddi, 4. Galesong, 5. Marina, 6. Bira, 7. Biringkassi
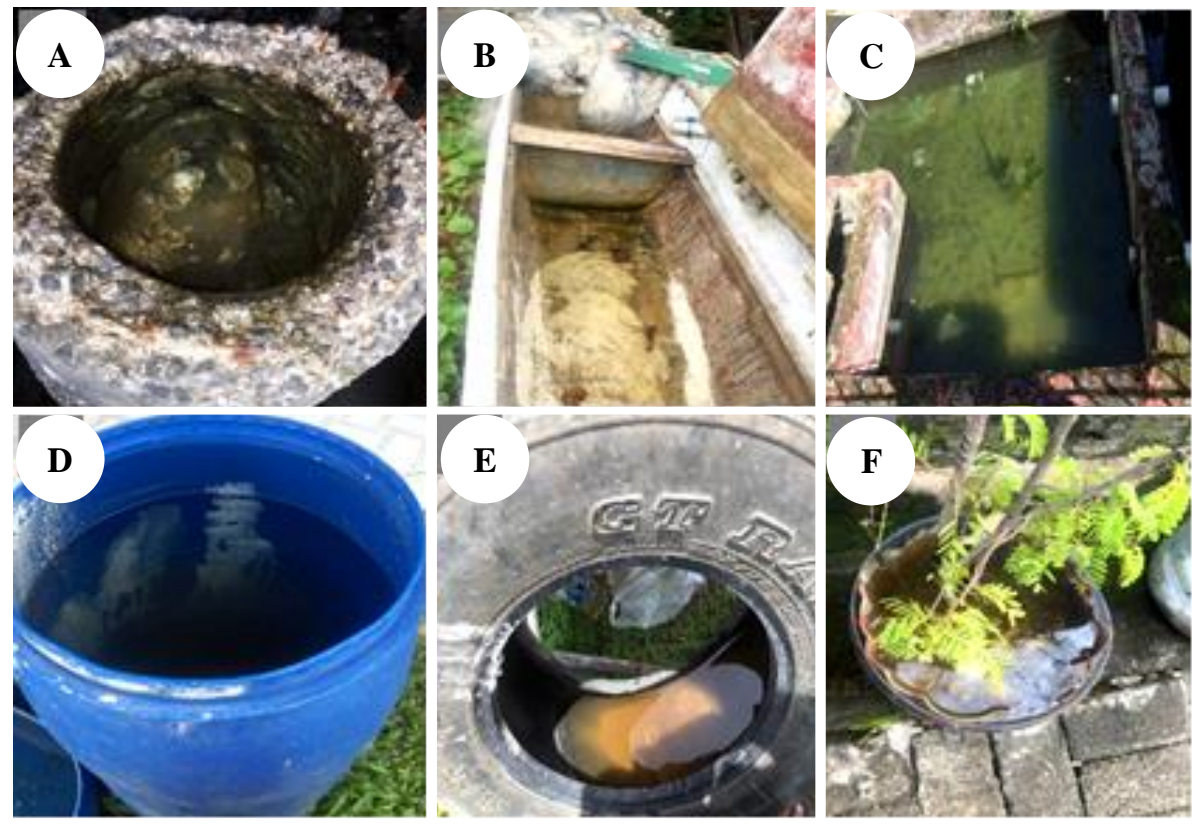

Figure 3. Containers in which larvae of Ae.aegypti and Ae.albopictus were found: A. Stone hole, B. Discarded boat, C. Unused pool, D. Water drum, E. Used tire, F. Flower pot

\section{Physical characteristics of larval habitats}

The physical characteristics of water are important factors for the success of breeding, survival, and adaptation of various organisms, including the larvae of Ae. aegypti and Ae. albopictus. Mosquitoes can breed in diverse environments and most larvae are found in freshwater near settlements. The temperature of mosquito larval habitat ranged from $27^{\circ} \mathrm{C}$ to $32^{\circ} \mathrm{C}$, the salt content $0 \mathrm{ppt}$ to $5 \mathrm{ppt}$, and the $\mathrm{pH} 5.5$ to 8 . The water in all places at a distance of $100 \mathrm{~m}$ from the coastline contained salt, while that in the other places did not, except for Brombong beach (Table 4).

\section{Factors correlated with the abundance of the mosquito larvae}

Pearson's correlation analysis showed several factors significantly correlated to the abundance of the mosquito larvae of Ae. aegypti and Ae. albopictus. The number of Ae. aegypti and Ae. albopictus larvae were significantly correlated with air $\mathrm{pH}$, temperature, and temporary water storage. The total number of larvae was significantly correlated with distance, salinity, permanent and temporary storage (Table 5). 
Table 4. Characters of physical factors of larval collection place in coastal habitat according to the distance from the sea

\begin{tabular}{|c|c|c|c|c|c|c|}
\hline \multirow{2}{*}{ Distance from coastline } & \multirow{2}{*}{ Larval collection places } & \multicolumn{3}{|c|}{ Physical factors } & \multicolumn{2}{|c|}{ Type of water } \\
\hline & & pH & Salt (ppt) & Temp $\left({ }^{\circ} \mathbf{C}\right)$ & Permanent & Temporary \\
\hline \multirow[t]{7}{*}{$100 \mathrm{~m}$} & Untia beach & 5.8 & 5 & 30 & No & Yes \\
\hline & Barombong beach & 6 & 3 & 29 & Yes & No \\
\hline & Kuri Caddi beach & 5.9 & 4 & 31 & Yes & No \\
\hline & Gallesong beach & 6.4 & 2 & 28 & No & Yes \\
\hline & Marina beach & 6 & 3 & 30 & No & Yes \\
\hline & Bira beach & 6 & 2 & 31 & Yes & No \\
\hline & Biringkassi beach & 5.5 & 5 & 30 & Yes & No \\
\hline \multirow[t]{7}{*}{$500 \mathrm{~m}$} & Untia beach & 7 & 0 & 27 & Yes & No \\
\hline & Barombong beach & 6.8 & 0.5 & 29 & No & Yes \\
\hline & Kuri Caddi beach & 7 & 0 & 28 & No & Yes \\
\hline & Gallesong beach & 7 & 0 & 30 & No & Yes \\
\hline & Marina beach & - & - & - & No & No \\
\hline & Bira beach & - & - & - & No & No \\
\hline & Biringkassi beach & 7 & 0 & 30 & Yes & Yes \\
\hline \multirow[t]{7}{*}{$1 \mathrm{~km}$} & Untia beach & - & - & - & No & No \\
\hline & Barombong beach & 8 & 0 & 29 & No & Yes \\
\hline & Kuri Caddi beach & 6 & 0 & 32 & No & Yes \\
\hline & Gallesong beach & 7.4 & 0 & 30 & No & Yes \\
\hline & Marina beach & - & - & - & No & No \\
\hline & Bira beach & - & - & - & No & No \\
\hline & Biringkassi beach & 6.8 & 0 & 27 & No & Yes \\
\hline \multirow[t]{7}{*}{$2 \mathrm{~km}$} & Untia beach & - & - & - & No & No \\
\hline & Barombong beach & 7.3 & 0 & 29 & No & Yes \\
\hline & Kuri Caddi beach & 7 & 0 & 31 & No & Yes \\
\hline & Gallesong beach & - & - & - & No & No \\
\hline & Marina beach & - & - & - & No & No \\
\hline & Bira beach & - & - & - & No & No \\
\hline & Biringkassi beach & 7.4 & 0 & 30 & No & Yes \\
\hline
\end{tabular}

Note: (Yes) There is/are above category/categories in the larvae collection place, (No) There is no above category in the larval collection place

Table 5. Factors correlated with the abundance of mosquito larvae in coastal areas

\begin{tabular}{clcccccc}
\hline \multicolumn{1}{c}{ Species } & & Distance & $\mathbf{p H}$ & Salinity & Temp & Permanent & Temporary \\
\hline Ae. aegypti & Pearson's coefficient of correlation & -0.174 & $.427^{*}$ & 0.211 & $.597^{* *}$ & 0.308 & $.390^{*}$ \\
& Sig. (2-tailed) & 0.377 & 0.023 & 0.281 & 0.001 & 0.110 & 0.040 \\
Ae. albopictus & Pearson coefficient of correlation & -0.101 & $.390^{*}$ & 0.113 & $.565^{* *}$ & 0.121 & $.406^{*}$ \\
& Sig. (2-tailed) & 0.609 & 0.040 & 0.567 & 0.002 & 0.541 & 0.032 \\
Total of larva & Pearson's coefficient of correlation & $.243^{* *}$ & 0.090 & $.426^{* *}$ & 0.055 & $-.213^{* *}$ & $.540^{* *}$ \\
& Sig. (2-tailed) & 0.000 & 0.106 & 0.000 & 0.327 & 0.000 & 0.000 \\
\hline
\end{tabular}

Note: *) Correlation is significant at the 0.05 level (2-tailed); **) Correlation is significant at the 0.01 level (2-tailed)

\section{Discussion}

Indonesia is a country with the highest incidence of dengue in Southeast Asia. Therefore, comprehension of the dynamics of dengue control should be based on identification of mosquito, reduction, and control of mosquito habitats (Satoto et al. 2014). DHF cases are still increasing in South Sulawesi, including Makassar, Maros, Takalar, Bantaeng, Bulukumba, and Pangkajene Islands. Coastal areas are a concern for dengue fever, and the outbreak can occur at any time. (Souza et al. 2019). Ae. albopictus and Ae. aegypti are competent vectors for Dengue DEN2-FJ10 and DEN2-FJ11 viruses (Guo et al. 2016).
This study demonstrates that the most abundant larvae of Ae. aegypti was found in Biringkassi coastal area with a distance of $2 \mathrm{~km}$ from the coastline, while that of Ae. albopictus in the Barombong coastal area. The abundance of Ae. aegypti and Ae. albopictus in the Biringkassi and Barombong coastal areas were related to proximity to settlements. According to Zahouli et al. (2016), the number of Aedes spp.can increase gradually with the distance traveled from rural areas $(\mathrm{n}=395 ; 33.4 \%)$ to urban areas which have many settlements $(n=1160 ; 100 \%)(Z=31.43$, $\mathrm{P}<0.001)$.

This study indicated differences in the percentage of larval species with a distance from coastline. Some 
mosquitoes are adapted to various types of environments (Rueda 2008), and Ae. aegypti is adapted to a habitat close to human settlements. The high density of Ae. aegypti and Ae. albopictus larvae in coastal areas were caused by the presence of discarded containers filled with seawater at high tide and rainwater, so they became suitable containers for breeding. The high density of mosquito in both studied areas reveal potential risk associated with the occurrence and transmission of vectorborne diseases (Manguin and Boete 2011).

Aedes aegypti and Ae.albopictus breeding places were mostly used tires, water drums, fishing boats, and several other types of artificial containers. Water drums were breeding places for both species in developing countries (Hemme et al. 2009). Other reports showed that used tires constituted $57.5 \%$ of Ae. aegypti breeding places (Ferede et al. 2018), 45\% of Ae. aegypti and Ae. albopictus (Futami et al. 2020), and $26.5 \%$ of Ae. aegypti and Ae.albopictus (Higa et al. 2010). Many used tires were found at home yard used as plant pots or other purposes. Besides, used tires are also used as fenders so that fishing vessels are not damaged when docked at the dock. The highest number of breeding places in the Barombong, Galesong, Marina, and Bira were water drums. Other studies reported the percentage of water drums being used as breeding places for Ae. aegypti was 19.3\% (Midega et al. 2006), 19.7\% (Ngugi et al. 2017), and 31.8\% (Tedjou et al. 2018). People use water drums in the four coastal areas, so they become potential breeding places for Ae. aegypti and Ae. albopictus. People who stay on the coastal areas use water drums to store freshwater, because it is difficult to get water for daily consumption.

Habitat of Ae. aegypti and Ae. albopictus in the Kuri Caddi Coastal was mostly fishing boats. Boat owners paid less attention to puddles on the boats because the boats were no longer used by the owners, and Ae. aegypti and Ae. albopictus made the puddle as a breeding place. Similar research found $42 \%$ of Ae. albopictus and $13 \%$ of Ae. aegypti bred on the boat (Ramasamy et al. 2011; Tsunoda et al. 2012). Many factors affect the density and diversity of mosquitoes, the most important of which is the availability of water because mosquito larvae need water to develop. The quality and characteristics of the water determine the species variety and composition of the mosquitoes (Bashar et al. 2016). The characteristics of habitat affected the survival of larvae and adults, which have the potential to influence arbovirus transmission. The presence of larvae was closely related to the availability of feed-in containers, adequate water volume at breeding sites, and the absence of predators that can threaten larval life (Barrera et al. 2006).

In this study site, the water in the containers had various $\mathrm{pH}$, salinity, and temperature, which would affect the survival of larvae. Clark et al. (2004) state that water $\mathrm{pH}$ affects the breeding success of larvae because Ae. aegypti cannot survive at $\mathrm{pH}<3$ or $>12$ and Medeiros et al. (2020) also say that Ae. aegypti and Ae. albopictus can reproduce in a habitat with a $\mathrm{pH}$ ranging from 4.2 to 9.8 . So, the density of mosquito larvae in the container has a significant correlation with the $\mathrm{pH}$ of water, i.e., $7.15 \pm 0$,
11 (Gopalakrishnan et al. 2013). Madzlan et al. (2016) reported a significant correlation between water $\mathrm{pH}(6.52 \pm$ $0.12-7.06 \pm 6.78$ ) with larval density.

The salinity of water also affects the larvae density because of adult female Ae. aegypti and Ae. albopictus prefer freshwater to lay its eggs (Hadi and Soviana 2013). Some studies reported that Ae. aegypti and Ae. albopictus reproduced in a habitat with salinity of less than 0.01 or 6.33 PSU (Medeiros et al. 2020), and $0.24 \pm 0.04 \mathrm{ppt}$ (Gopalakrishnan et al. 2013). In this study, most locations did not have salt in the containers except for the location at a distance of $100 \mathrm{~m}$ from the coastline.

The larval density is also correlated with temperature of water (Vanlalruia et al. 2014). Medeiros et al. (2020) reported that the temperature for Ae. aegypti and $A e$. albopictus reproduction ranged from minimum of $9.8^{\circ} \mathrm{C}$ up to maximum of $32^{\circ} \mathrm{C}$. Meanwhile, Madzlan et al. (2016) reported a significant correlation between water temperature $\left(29.28 \pm 0.20^{\circ} \mathrm{C}\right)$ and larval density. The temperature in this study site ranged from $27^{\circ} \mathrm{C}$ to $32^{\circ} \mathrm{C}$ which is within the tolerable range for larval development.

Mosquitoes are formidable disease vectors because they are distributed globally and are adapted to a broad range of environmental conditions (Chandrasegaran et al. 2020). They can breed in a variety of habitats, including forests, mountains, plains, deserts, tropical forests, salt marshes, and tidal zones (Foster and Walker 2019). Liu et al. (2016) predicted that Ae. aegypti and Ae. albopictus would expand their range to various levels of climate.

This study concluded that mosquitos breed in many types of water containers neglected by people. Educating the people to remove the neglected water will reduce the density of the mosquito, thus reducing the cases of dengue fever.

\section{ACKNOWLEDGEMENTS}

The authors wish to thank Indonesian Ministry of Education and Culture, and Faculty of Medicine, Hasanuddin University, Makassar, Indonesia for their support to the research reported here.

\section{REFERENCES}

Arana-Guardia R, Baak-Baak CM, Loroño-Pino MA, Machain-Williams C, Beaty BJ, Eisen L, García-Rejón JE. 2014. Stormwater drains and catch basins as sources for production of Aedes aegypti and Culex quinquefasciatus. Acta Trop 134 (1): 33-42. DOI: 10.1016/j.actatropica.2014.01.011.

Barrera R, Amador M, Clark GG. 2006. Ecological factors influencing Aedes aegypti (Diptera: Culicidae) productivity in artificial containers in Salinas, Puerto Rico. J Med Entomol 43 (3): 484-492.

Bashar K, Rahman MS, Nodi IJ, Howlader AJ. 2016. Species composition and habitat characterization of mosquito (Diptera: Culicidae) larvae in semi-urban areas of Dhaka, Bangladesh. Pathog Glo Health 110 (2): 48-61.

BMKG. 2019. Data Pemantauan Iklim Indonesia Tahun 2019. BMKG, Jakarta, Indonesia. [Indonesian]

Chandrasegaran K, Lahondère C, Escobar EL, Vinauger C. 2020. Linking mosquito ecology, traits, behavior, and disease transmission. Trends Parasitol 36 (4): 393-403. DOI: 10.1016/j.pt.2020.02.001. 
Clark MT, Flis BJ, Remold SK. 2004. pH tolerances and regulatory abilities of freshwater and euryhaline Aedine mosquito larvae. J Exp Biol 207: 2297-2304. DOI: 10.1242/jeb.01021.

Ferede G, Tiruneh M, Abate E, Kassa WJ, Wondimeneh Y, Damtie D, Tessema B. 2018. Distribution and larval breeding habitats of Aedes mosquito species in residential areas of northwest Ethiopia. Epidemiol Health 40: e2018015. DOI: 10.4178/epih.e2018015.

Foster WA, Walker ED. 2019. Mosquitoes (Culicidae). Med Vet Entomol. DOI: 10.1016/b978-0-12-814043-7.00015-7.

Futami K, Iwashita H, Higa Y, Lutiali PA, Sonye GO, Mwatele C, Njenga SM, Minakawa N2020. Geographical distribution of Aedes aegypt and Aedes aegypti formosus (Diptera: Culicidae) in Kenya and environmental factors related to their relative abundance. J Med Entomol 57 (3): 772-779. DOI: 10.1093/jme/tjz233.

Gopalakrishnan R, Das M, Baruah I, Veer V, Dutta P. 2013 Physicochemical characteristics of habitats in relation to the density of container-breeding mosquitoes in Asom, India. J Vec Borne Dis 50 (3): $215-219$

Guo XX, Li CX, Zhang YM, Xing D, Dong YD, Zhang HD, Qin CF, Zhao TY. 2016. Vector competence of Aedes albopictus and Aedes aegypti (Diptera: Culicidae) for the DEN2-FJ10 and DEN2-FJ11 strains of the dengue 2 virus in Fujian, China. Acta Trop 161: 86-90. DOI: $10.1016 /$ j.actatropica.2016.05.018.

Hadi UK, Soviana S. 2013. Ectoparasites. Introduction, Identification and Control. 3rd ed. IPB Press, Bogor. [Indonesian]

Hemme RR, Tank JL, Chadee DD, Severson DW. 2009. Environmental conditions in water storage drums and influences on Aedes aegypti in Trinidad, West Indies. Acta Trop 112 (1): 59-66. DOI: 10.1016/j.actatropica.2009.06.008.

Higa Y, Thi Yen N, Kawada H, Son TH, Hoa NT, Takagi M. 2010. Geographic distribution of Aedes aegypti and Aedes albopictus collected from used tires in Vietnam. J Am Mosq Control Assoc 26 (1) : 1-9. DOI: 10.2987/09-5945.1.

Ibáñez-Justicia A, Juan D, Hernandez A, van Lammeren R, Koenraad CJM, Bergsma A, Delucchi L, Rizzoli A, Takken W. 2020. Habitat suitability modelling to assess the introductions of Aedes albopictus (Diptera: Culicidae) in the Netherlands. Parasites and Vector 13: 217. DOI: 10.1186/s13071-020-04077-3.

Kauffman E, Payne A, Franke M, Schmid MA, Harris E, Kramer LD 2017. Rearing of Culex spp. and Aedes spp. Mosquitoes. Bio Protoc 5 (17): e2542. DOI: 10.21769/bioprotoc.2542.

Lambrechts L, Scott TW, Gubler DJ. 2010. Consequences of the expanding global distribution of Aedes albopictus for dengue virus transmission. PLoS NTDs 4 (5): e646. DOI: 10.1371/journal.pntd.0000646.

Liu HJ, Quam M, Wilder SA, Stenlund H, Ebi K, Massad E, Rocklöv J. 2016. Climate change and Aedes vectors: 21 st-century projections for dengue transmission in Europe. EBioMed 7: 267-277. DOI: 10.1016/j.ebiom.2016.03.046.

Lubinda J, Treviño CJA, Walsh MR, Moore AJ, Hanafi-Bojd AA, Akgun S, Zhao B, Barro AS, Begum MM, Jamal H, Angulo-Molina A, Haque U. 2019. Environmental suitability for Aedes aegypti and Aedes albopictus and the spatial distribution pattern of major arboviral infections in Mexico. J Parasite Epidemiol Control 6: e00116. DOI: 10.1016/j.parepi.2019.e00116.

Madzlan F, Dom NC, Tiong CS, Zakaria N. 2016. Breeding characteristics of Aedes mosquitoes in dengue risk area. Proc Soc Behav Sci 234: 164-172. DOI: 10.1016/j.sbspro.2016.10.231.

Manguin S, Boete C. 2011. Global impact of mosquito biodiversity, human vector-borne diseases and environmental change. In: The Importance of Biological Interactions in the Study of Biodiversity. IntechOpen Limited, London. DOI: 10.5772/22970.

Medeiros SR, Oliveira CR, Camargo AA, Scinachi CA, Milani GM, Urbinatti PR, Natal D, Ceretti-Junior W, Marrelli MT. 2020. Influence of water's physical and chemical parameters on mosquito (Diptera: Culicidae) assemblages in larval habitats in urban parks of Sao Paulo, Brazil. J Pre-proof Acta Trop. DOI: 10.1016/j.actatropica.2020.105394

Midega JT, Nzovu J, Kahindi S, Sang RC, Mbogo C. 2006. Application of the pupal/demographic-survey methodology to identify the key container habitats of Aedes aegypti (L.) in Malindi District, Kenya. Ann Trop Med Parasitol 100: 61-72. DOI: $10.1179 / 136485906 \times 105525$.

Ministry of Health Indonesia. 2018. Situasi Penyakit Demam Berdarah di Indonesia Tahun 2017. Pusat Data dan Informasi Kementrian Kesehatan RI, Indonesia. [Indonesian]
Ministry of Health Indonesia. 2017. Guidelines for Dengue Fever Entomology Survey and Key to Identification of Aedes Mosquitoes. Ministry of Health, Jakarta. [Indonesian]

Ngugi HN, Mutuku FM, Ndenga BA, Musunzaji SP, Mbakaya JO, Aswani P, Irungu LW, Mukoko D, Vulule J, Kitron U, LaBeaud AD. 2017. Characterisation and productivity profiles of Aedes aegypti (L.) breeding habitats across rural and urban landscapes in western and coastal Kenya. Parasites Vectors 10 (1): 1-12. DOI: 10.1186/s13071017-2271-9

Paupy C, Ollomo B, Kamgang B, Moutailler S, Rousset D, Demanou M, Hervé JP, Leroy E, Simard F. 2010. Comparative role of Aedes albopictus and Aedes aegypti in the emergence of dengue and chikungunya in Central Africa. Vector-Borne Zoonotic Dis 10 (3): 256-266. DOI: 10.1089/vbz.2009.0005

Pratiwi R, Anwar C, Salni, Hermansyah, Novrikasari, Ghiffari A, Putra R, Huda A. 2019. Species diversity and community composition of mosquitoes in a filariasis endemic area in Banyuasin District, South Sumatra, Indonesia. Biodiversitas 20 (2): 453-462. DOI: 10.13057/biodiv/d200222

Ramasamy R, Surendran SN, Jude PJ, Dharshini S, Vinobaba M. 2011. Larval development of Aedes aegypti and Aedes albopictus in periurban brackish water and its implications for transmission of arboviral diseases. PLoS NTDs 5 (11): e1369. DOI: 10.1371/journal.pntd.0001369

Rueda LM. 2008. Freshwater Animal Diversity Assessment. DOI: 10.1007/978-1-4020-8259-7

Sasmono RT, Wahid I, Trimarsanto H, Yohan B, Wahyuni S, Hertanto M, Yusuf I, Mubin H, Ganda IJ, Latief R, Bifani PJ, Shi PY, Schreiber MJ. 2015. Genomic analysis and growth characteristic of dengue viruses from Makassar, Indonesia. Infect Genet Evol 32: 165-177. DOI: 10.1016/j.meegid.2015.03.006

Satoto TBT, Umniyati SR, Astuti FD, Wijayanti N, Gavotte L, Devaux C, Frutos R. 2014. Assessment of vertical dengue virus transmission in Aedes aegypti and serotype prevalence in Bantul, Indonesia. Asian Pac J Trop Dis 4 (2): S563-S568. DOI: 10.1016/S22221808(14)60677-0

Silva WR, Soares SJ, Ferreira FA, Rodrigues IB, Tadei WP, Zequi JAC. 2018. Oviposition of Aedes aegypti Linnaeus and Aedes albopictus Skuse (Diptera: Culicidae) under laboratory and field conditions using ovitraps associated to different control agents, Manaus, Amazonas, Brazil. Rev Bras Entomol 62 (4): 304-310. DOI: 10.1016/j.rbe.2018.08.001.

Soares SJ, Ibiapina SS, Bezerra JMT, Tadei WP, Pinheiro VCS. 2012. Variation in Aedes aegypti (Linnaeus) (Diptera, Culicidae) infestation in artificial containers in Caxias, state of Maranhão, Brazil. Rev Soc Bras Med Trop 45 (2): 174-179. DOI: 10.1590/S003786822012000200007.

Souza NJA, Powell JR, Bonizzoni M. 2019. Aedes aegypti vector competence studies: A review. Infect Genet Evol 67: 191-209. DOI: 10.1016/j.meegid.2018.11.009.

Tedjou AN, Kamgang, B, Yougang AP, Njiokou F, Wondji CS. 2018. Update on the geographical distribution and prevalence of Aedes aegypti and Aedes albopictus (Diptera: Culicidae), two major arbovirus vectors in Cameroon. PLoS NTDs 13 (3): 1-18. DOI: 10.1371/journal.pntd.0007137.

Tsunoda T, Fukuchi A, Nanbara S, Higa Y, Takagi M. 2012. Aedes mosquito larvae collected from Ishigaki-jima and Taketomi-jima Islands in southern Japan. Southeast Asian J Trop Med Public Health 43 (6): 1375-1379.

Vanlalruia K, Senthilkumar N, Gurusubramanian G. 2014. Diversity and abundance of mosquito species in relation to their larval habitats in Mizoram, North Eastern Himalayan region. Acta Trop 137: 1-18. DOI: 10.1016/j.actatropica.2014.04.026.

Wilkerson RC, Linton Y, Fonseca DM, Schultz TR, Price DC, Strickman DA. 2015. Making mosquito taxonomy useful: A stable classification of tribe Aedini that balances utility with current knowledge of evolutionary relationships. PLoS ONE 10 (7): e0133602. DOI: 10.1371/journal.pone.0133602.

Zahouli JBZ, Utzinger J, Adja MA, Müller P, Malone D, Tano Y, Koudou BG. 2016. Oviposition ecology and species composition of Aedes spp. and Aedes aegypti dynamics in variously urbanised settings in arbovirus foci in southeastern Côte d'Ivoire. Parasites and Vectors 9 (1): 1-14. DOI: $10.1186 / \mathrm{s} 13071-016-1778-9$ 